Originales

\title{
Comparison of bronchoscopic bronchoalveolar lavage vs blind lavage with a modified nasogastric tube in the etiologic diagnosis of ventilator-associated pneumonia
}

\author{
A. LEO ${ }^{a}$, J. GALINDO-GALINDOª, E. FOLCH ${ }^{b}$, A. GUERREROa, F. BOSQUES ${ }^{a}$, R. MERCADO \\ AND A.C. ARROLIGAc \\ aHospital Universitario Dr. José Eleuterio González. Monterrey. México. \\ ${ }^{b}$ Department of Pulmonary, Allergy and Critical Care Medicine. The Cleveland Clinic. Cleveland. Ohio. USA. \\ 'Division of Pulmonary and Critical Care Medicine. Scott \& White Hospital. Temple. Texas. USA.
}

Objective. Our objective was to compare the results of a blind lavage vs a bronchoscopic-guided bronchoalveolar lavage for the etiologic diagnosis of ventilator-associated pneumonia (VAP).

Design. Prospective study in consecutive patients with high probability of VAP. Every patient underwent both procedures, in a formally randomized fashion. The interpretation of quantitative cultures was done in a blind fashion.

Setting. Single center study, with a 20 bed medical and surgical Intensive Care Unit of the University Hospital in Monterrey, Mexico.

Patients. Twenty-five patients with high probability of VAP.

Interventions. Every patient underwent blind bronchoalveolar lavage with a modified nasogastric tube, and a bronchospic-guided bronchoalveolar lavage.

Results. Twenty-one patients underwent both procedures. Four patients were excluded due to contamination of the cultures. The quantitative cultures were compared in a paired fashion. Only two patients had discordant cultures. The correlation coefficient between the number of colonies was very high, $r=0.90(95 \%$ confidence interval [Cl], 0.77-0.96; $p=0.0001$ ).

Correspondence: Dr. A.C. Arroliga

Scott \& White Hospital.

2401 South 31st Street.

Temple, TX 76508. USA

e-mail: aarroliga@swmail.sw.org

Manuscript accepted on 8-VIII-2007.
Conclusions. The blind bronchoalveolar lavage with a modified nasogastric tube is a valuable tool for the identification of etiologic agent in VAP, particularly when trained bronchoscopists or the necessary resources for bronchoscopic-guided bronchoalveolar lavage are not readily available.

KEY WORDS: ventilator-associated pneumonia, bronchoalveolar lavage, nasogastric tube, blind bronchoalveolar lavage.

\section{COMPARACIÓN DE LAVADO}

BRONCOALVEOLAR BRONCOSCÓPICO FRENTE A LAVADO CIEGO CON SONDA NASOGÁSTRICA MODIFICADA EN EL DIAGNÓSTICO ETIOLÓGICO DE NEUMONÍA ASOCIADA A VENTILADOR

Objetivo. Nuestro objetivo fue el de comparar los resultados de un lavado ciego frente a un lavado broncoalveolar guiado con broncoscopio para el diagnóstico etiológico de neumonía asociada a ventilador (NAV).

Diseño. Estudio prospectivo en pacientes consecutivos con alta probabilidad de NAV. En todos los pacientes se llevaron a cabo ambos procedimientos de manera aleatorizada. La interpretación de los cultivos cuantitativos fue hecha a ciegas.

Ámbito. Estudio en un único centro, en una Unidad de Cuidados Intensivos Quirúrgicos con 20 camas del Hospital Universitario de Monterrey, en México.

Pacientes. Veinticinco pacientes con alta probabilidad de NAV.

Intervenciones. A cada paciente se le realizó un lavado broncoalveolar ciego con una sonda na- 
sogástrica modificada y un lavado broncoalveolar guiado con broncoscopio.

Resultados. Se realizaron ambos procedimientos en 21 pacientes. Cuatro fueron excluidos debido a contaminación de los cultivos. Los cultivos cuantitativos fueron comparados en pares. Solo dos pacientes tenían cultivos discordantes. El coeficiente de correlación entre el número de colonias fue muy alto, $r=0,90$ (intervalo de confianza [IC] del 95\% 0,77-0,96; $p=0,0001$ ).

Conclusiones. El lavado broncoalveolar ciego con sonda nasogástrica modificada es una herramienta de mucho valor para la identificación del agente etiológico en NAV, especialmente cuando un broncoscopista experto o los recursos necesarios para lavado broncoalveolar guiado con broncoscopio no están fácilmente disponibles.

PALABRAS CLAVE: neumonía asociada a ventilador, lavado broncoalveolar, sonda nasogástrica, lavado broncoalveolar ciego.

\section{INTRODUCTION}

Ventilator-associated pneumonia (VAP) is a major medical problem. VAP is associated with longer stay in the Intensive Care Unit (ICU) and in the hospital, high cost, and high mortality rates ${ }^{1-5}$. The clinical diagnosis of VAP that includes radiographic changes and at least one clinical finding such as fever, leukocytosis, or purulent tracheal aspirate has a good sensitivity but poor specificity ${ }^{4}$. It has been recommended that a sample of the lower respiratory tract should be obtained when the clinical diagnoses of VAP is suspected ${ }^{4}$. Invasive diagnostic testing may increase the confidence of the clinician in the diagnosis and management of the VAP and because of the good negative predictive value thus allowing discontinuation of antibiotic therapy ${ }^{4,6}$.

Quantitative cultures of specimens taken with bronchoscopic techniques or through blind non-bronchoscopic techniques are appealing alternatives for the collection of lower respiratory tract specimens ${ }^{4}$. A strategy of diagnosis that includes obtaining a sample by bronchoscopic technique is associated with a lower mortality at day 14 and a decrease in antibiotic use ${ }^{7}$. However, bronchoscopy may not be readily avail$\mathrm{able}^{4}$, especially in countries with limited resources, therefore diagnostic testing with non-bronchoscopic techniques and early use of broad-spectrum antibiotics are attractive options in order to minimize cost, antibiotic use, as well as improve survival ${ }^{8}$.

The hypothesis of the study is that the isolated bacteria and quantitative cultures would be similar in the fluid obtained with both techniques. The goal of this study was to compare the microbiologic findings in lower airway lavage through a non-bronchoscopic technique using a modified nasogastric tube ${ }^{9}$ against a fiberoptic bronchoscope-directed bronchoalveolar lavage (BAL) in the same patient.

\section{PATIENTS AND METHODS}

We prospectively studied 25 patients with suspected VAP in the Medical and Surgical ICU at Hospital Universitario Dr. José Eleuterio González between June 1, 2005 and June 1, 2006. This hospital is a major teaching hospital in Monterrey, Mexico. The unit has 20 beds, staffed by residents in Internal Medicine, Fellows in Pulmonary and Critical Care, and Attending Intensive Care specialists. The ratio of patients per nurses is $2: 1$.

Patients were eligible for the study if they met the following inclusion criteria: $\geq 18$ year-old, intubated for more than 48 hours, who met the clinical definition for VAP. Clinical definition of VAP refers to new infiltrates in the chest X-ray with $\geq 2$ of the following: fever or hypothermia $\left(\leq 35^{\circ} \mathrm{C}\right.$ or $\left.\geq 38.3^{\circ} \mathrm{C}\right)$, leukocytosis or leukopenia $(\geq 12,000 / \mathrm{dl}$ or $\leq$ $4,000 / \mathrm{dl})$, purulent secretions in the endotracheal tube (ETT), and/or poor oxygenation $\left(\mathrm{PaO}_{2} / \mathrm{FiO}_{2} \leq\right.$ $240 \mathrm{mmHg})^{1,4}$. Patients were excluded if they had a contraindication for bronchoscopy (for example severe hypoxemia $\mathrm{PaO}_{2} / \mathrm{FiO}_{2}<100 \mathrm{mmHg}$ ), refractory coagulopathy (prothrombin time and partial thromboplastin time $>$ twice the upper limit of normal nonresponsive to $10 \mathrm{cc} / \mathrm{kg}$ of fresh frozen plasma $[\mathrm{FFP}]$ ), or hemodinamically unstable at time of bronchoscopy (mean arterial pressure $[\mathrm{MAP}]<60 \mathrm{mmHg}$ ).

The study was approved by the Institutional Review Board, and informed consent was obtained from the patient or next of kin.

The following characteristics were recorded prospectively at the time of ICU admission: age, sex, APACHE II score ${ }^{10}$, main diagnosis and comorbidities, clinical pulmonary infection score (CPIS $)^{11}$, previous antibiotics, concurrent extrapulmonary infections, and radiologic findings. The CPIS and APACHE II scores were calculated again on the day of the study. Every study participant underwent two procedures:

1. Blind BAL with a modified nasogastric tube (non-bronchoscopic).

2. BAL using a standard fiberoptic bronchoscope.

The modification in the nasogastric tube consists in the cutting of the tip of the catheter to remove the area with multiple holes ${ }^{9}$. We randomly determined which procedure was done first. The procedures were performed 20 minutes apart for stabilization purposes.

Patients were sedated and preoxygenated while on continuous pulse oxymetry monitoring. For the nonbronchoscopic procedure, a 14F nasogastric tube was slowly introduced through an adaptor (Portex ${ }^{\circledR}$, Keene, New Hampshire, USA) into the ETT, until resistance was felt. Three aliquots of $50 \mathrm{ml}$ of sterile $0.9 \%$ saline were instilled sequentially, and withdrawn by manual suction with a $50 \mathrm{ml}$ catheter-tip piston syringe. The first aspirate was discarded. The remaining two aspirates were processed in the Microbiology laboratory. In the bronchoscopic procedure, after tracheal aspiration, the fiberoptic bronchoscope (Pentax ${ }^{\circledR}$, Orangeburg, New York, USA) was introduced into the ETT via the ETT adaptor and positioned («wedged») in the orifice of the sampling 
TABLE 1. Clinical characteristics of study subjects

\begin{tabular}{|l|c|}
\hline \multicolumn{1}{|c|}{ Characteristic } & Mean $\pm \mathrm{SD}$ \\
\hline Age, year (range) & $42(17-82)$ \\
Sex (male) & 14 \\
APACHE II on admission & $13 \pm 7$ \\
$\mathrm{APACHE}$ II at time of procedure & $15 \pm 8$ \\
$\mathrm{PaO}_{2} / \mathrm{FiO}_{2}$ & $213 \pm 81$ \\
$\mathrm{CPIS}_{2}$ on the day of study & $7.5 \pm 1.54$ \\
Days intubated & $8 \pm 4$ \\
Temperature $\left({ }^{\circ} \mathrm{C}\right)$ & $38.1 \pm 0.81$ \\
White blood cell count $\left(\times 10^{9} / 1\right)$ & $16 \pm 9.1$ \\
Radiologic pattern & $14(66 \%)$ \\
$\quad$ Diffuse & $7(33 \%)$ \\
Focal & \\
\hline
\end{tabular}

CPIS: Clinical Pulmonary Infection Score; SD: standard deviation.

area with sequential instillation of three aliquots of 50 $\mathrm{ml}$ of sterile $0.9 \%$ saline. The first aspirate was discarded, and remaining fluid was sent to the Microbiology laboratory. No aspiration was done through the working channel of the bronchoscope before the collection of samples in order to minimize contamination.

The specimens were immediately sent to the laboratory and processed according to previously described methods by Baselski ${ }^{12}$. The samples were centrifuged for 30 seconds, a Gram stain was done searching for intracellular organisms. The bacterial cultures were processed with microorganisms quantified by an experienced microbiologist using standard serial dilution and the results were expressed as colony-forming units $(\mathrm{cfu} / \mathrm{ml})^{13}$. The cut-off point for significant growth was $10^{4} \mathrm{cfu} / \mathrm{ml}$ for both procedures $^{14,15}$. The microbiologist reading the cultures was blinded for which procedure was used and for the result of the corresponding sample.

\section{Statistical analysis}

Descriptive statistics were used, with all comparisons being paired, and all tests of significance two tailed. All values are expressed as the mean \pm standard deviation (SD). Sensitivity, specificity, positive predictive value, negative predictive value, and likelihood ratios were determined considering fiberoptic bronchoscopy (FOB) with BAL as the gold standard. Correlation coefficients were also calculated.

\section{RESULTS}

Twenty-five eligible patients were included in the study, with 4 patients being excluded from analysis due to contamination of microbiology cultures. The 21 subjects ( 14 men and 7 women) had a mean age of 42 years-old (range 17-82), with mean APACHE II score of $15( \pm 8)$ and a CPIS of 7.5 on the day of the procedures (table 1). The reasons for hospital admission were pneumonia (5), trauma (4), sepsis (2), stroke (1), burns (1), severe pancreatitis (1), eclampsia
(1), brain tumor (1), empyema (1), aortic aneurysm (1), pulmonary hemorrhage (1), hypovolemic shock (1), and respiratory failure (1). All patients were intubated, and 15 of 21 had been receiving antibiotics for the reason that prompted their admission to the ICU.

Every patient underwent both bronchoscopic and non-bronchoscopic procedures. The mean volume of fluid recovered from lavage was $42 \pm 8 \mathrm{ml}$ in the bronchoscopic technique and $40 \pm 10 \mathrm{ml}$ in the nonbronchoscopic technique. With the bronchoscopic technique, significant growth was found in $66.7 \%$ (n =14) of the samples and non-significant growth in $33.3 \%(n=7)$. With the non-bronchoscopic technique significant growth was found in $71.4 \%(n=15)$ of the samples, non-significant growth in $28.6 \%(\mathrm{n}=$ 6) (tables 2 and 3).

The quantitative cultures obtained through either technique are shown in table 3. Only two patients had discordant cultures, the non-bronchoscopic technique failed to provide quantitative evidence of infection in one case, and it identified a second organism inanother patient, that was not isolated with the bronchoscopic technique.

The most common isolated organisms were Staphylococcus aureus, Acinetobacter baumannii, and Pseudomonas aeruginosa with polymicrobial infection present in $16(76.2 \%)$ cases, and single organism infection present in $14.3 \%$ of the cases. The Spearman's coefficient of rank correlation (r) for number of colonies showed a positive correlation at 0.90 (confidence interval [CI] 0.77-0.96; $p=0.0001$ ) between the two techniques. The sensitivity of the non-bronchoscopic technique was $93 \%$, and the specificity was $85 \%$ when compared to the bronchoscopic-guided bronchoalveolar lavage (table 4). We calculated the likelihood ratios ${ }^{16}$ or how many times more likely patients with the disease are to have that particular result than patients without the disease. The positive and negative likelihood ratios showed strong evidence to rule in or out the presence of VAP in this group of patients. The procedures were tolerated well with no episodes of desaturation below $88 \%$ with either technique.

\section{DISCUSSION}

In this single center, prospective study we demonstrated the excellent operating characteristics of a non-bronchoscopic BAL technique using a nasogastric tube compared with the frequently cited fiberoptic bronchoscope-guided BAL.

There is currently no gold standard for the diagnosis of VAP and clinicians rely on clinical and bacteriologic strategies to manage patients with $\mathrm{VAP}^{4}$. The bacteriologic strategy uses quantitative cultures of lower respiratory secretions and has been associated with less use of antibiotics. In a seminal paper, Fagon et al showed that an invasive strategy using FOB with quantitative cultures improves survival (14 days), and decreases antibiotic use ${ }^{7}$. Eventhough the bronchoscopically-guided BAL has several advantages, the most important being the ability to direct 
TABLE 2. Comparison of culture results for bronchoscopic and non-bronchoscopic procedures in patients with significant growth (>104 $\mathrm{cfu}$ )

\begin{tabular}{|c|c|c|c|}
\hline Patient & Diagnosis & Non-bronchoscopic (blind) & Bronchoscopic \\
\hline 1 & Pneumonia & Pseudomonas aeruginosa & Pseudomonas aeruginosa \\
\hline 3 & Brainstem tumor & $\begin{array}{l}\text { Acinetobacter baumannii } \\
\text { Escherichia coli } \\
\text { Staphylococcus aureus }\end{array}$ & $\begin{array}{c}\text { Acinetobacter baumannii } \\
\text { Escherichia coli } \\
\text { Staphylococcus aureus }\end{array}$ \\
\hline 4 & Pneumonia & $\begin{array}{l}\text { Staphylococcus aureus } \\
\text { Klebsiella pneumoniae }\end{array}$ & $\begin{array}{l}\text { Staphylococcus aureus } \\
\text { Klebsiella pneumoniae }\end{array}$ \\
\hline 6 & Severe pancreatitis & $\begin{array}{l}\text { Pseudomonas aeruginosa } \\
\text { Staphylococcus aureus }\end{array}$ & $\begin{array}{l}\text { Pseudomonas aeruginosa* } \\
\text { Staphylococcus aureus }\end{array}$ \\
\hline 7 & Burns and pneumonitis & $\begin{array}{c}\text { Pseudomonas aeruginosa } \\
\text { Staphylococcus aureus } \\
\text { Stenotrophomonas maltophilia }\end{array}$ & $\begin{array}{c}\text { Pseudomonas aeruginosa } \\
\text { Staphylococcus aureus } \\
\text { Stenotrophomonas maltophilia }\end{array}$ \\
\hline 8 & Abdominal aortic aneurysm & $\begin{array}{l}\text { Acinetobacter baumannii } \\
\text { Staphylococcus sciuri }\end{array}$ & $\begin{array}{l}\text { Acinetobacter baumannii } \\
\text { Staphylococcus sciuri }\end{array}$ \\
\hline 9 & Pneumonia & $\begin{array}{l}\text { Acinetobacter baumannii } \\
\text { Staphylococcus aureus }\end{array}$ & $\begin{array}{l}\text { Acinetobacter baumannii } \\
\text { Staphylococcus aureus }\end{array}$ \\
\hline 10 & Pulmonary hemorrhage & $\begin{array}{l}\text { Acinetobacter baumannii } \\
\text { Citrobacter freundii }\end{array}$ & $\begin{array}{l}\text { Acinetobacter baumannii } \\
\text { Citrobacter freundii }\end{array}$ \\
\hline 11 & Hypovolemic shock & $\begin{array}{l}\text { Acinetobacter baumannii } \\
\text { Staphylococcus aureus }\end{array}$ & $\begin{array}{l}\text { Acinetobacter baumannii } \\
\text { Staphylococcus aureus }\end{array}$ \\
\hline 12 & Sepsis & $\begin{array}{l}\text { Acinetobacter baumannii } \\
\text { Staphylococcus aureus }\end{array}$ & $\begin{array}{l}\text { Acinetobacter baumannii } \\
\text { Staphylococcus aureus }\end{array}$ \\
\hline 14 & Pneumonia & $\begin{array}{l}\text { Pseudomonas aeruginosa } \\
\text { Staphylococcus aureus }\end{array}$ & $\begin{array}{l}\text { Pseudomonas aeruginosa } \\
\text { Staphylococcus aureus }\end{array}$ \\
\hline 15 & Sepsis & $\begin{array}{c}\text { Acinetobacter baumannii } \\
\text { Stenotrophomonas maltophilia }\end{array}$ & $\begin{array}{c}\text { Acinetobacter baumannii } \\
\text { Stenotrophomonas maltophilia }\end{array}$ \\
\hline 16 & Trauma & $\begin{array}{c}\text { Pseudomonas aeruginosa } \\
\text { Staphylococcus aureus }\end{array}$ & $\begin{array}{c}\text { Pseudomonas aeruginosa } \\
\text { Staphylococcus aureus }\end{array}$ \\
\hline 19 & Trauma & $\begin{array}{c}\text { Stenotrophomonas maltophilia } \\
\text { Acinetobacter baumannii } \\
\text { Staphylococcus aureus } \\
\text { Pseudomonas aeruginosa }\end{array}$ & $\begin{array}{c}\text { Stenotrophomonas maltophilia } \\
\text { Acinetobacter baumannii } \\
\text { Staphylococcus aureus }\end{array}$ \\
\hline 20 & Trauma & Staphylococcus aureus & $\begin{array}{c}\text { Staphylococcus aureus } \\
\text { Escherichia coli }\end{array}$ \\
\hline
\end{tabular}

*The bronchoscopic technique showed growth below the threshold $\left(<10^{4} \mathrm{cfu}\right)$ and was considered negative. cfu: colony-forming units.

sampling into the desired lobe, it is important to emphasize its limitations in resource constrained settings. Fiberoptic bronchoscopes and qualified operators are not always readily available, thus potentially delaying pathogen-directed treatment with its harmful consequences ${ }^{17,18}$. Previous reports of «blind» invasive procedures have yield conflicting evidence, mostly because of variable methodologies, different thresholds of the quantitative studies, and reference standards ${ }^{11,19-26}$. Minutoli et al reported in the late 1980 s the use of a nasogastric tube to do bronchoalveolar lavages in patients with the acquired im- munodeficiency syndrome 9 . We extended their experience using this technique to obtain distal airway sample for bacterial cultures of patients with high clinical suspicion of VAP.

In an attempt to standardize a technique that should be simple, widely available, inexpensive, and with low risk of complications, we analyzed the performance of the nasogastric tube with quantitative cultures side-by-side with the bronchoscopy-directed BAL in the same patient with excellent results. By using the exact same lavage volume, quantitative threshold, and discarding the first aspirate, we ob-

TABLE 3. Comparison of culture results for bronchoscopic and non-bronchoscopic procedures in patients with non-significant growth $\left(<10^{4} \mathrm{cfu}\right)$

\begin{tabular}{|c|c|c|c|}
\hline Patient & Diagnosis & Non-bronchoscopic (blind) & Bronchoscopic \\
\hline 2 & HAP & Acinetobacter baumannii & Acinetobacter baumannii \\
\hline 5 & Eclampsia & $\begin{array}{l}\text { Pseudomonas putida } \\
\text { Enterobacter cloacae }\end{array}$ & $\begin{array}{l}\text { Pseudomonas putida } \\
\text { Enterobacter cloacae }\end{array}$ \\
\hline 13 & Respiratory acidosis & Normal flora & Normal flora \\
\hline 17 & Trauma & No growth & No growth \\
\hline 18 & Empyema & Klebsiella pneumoniae & Klebsiella pneumoniae \\
\hline & & $\begin{array}{l}\text { Acinetobacter baumannii } \\
\text { Staphylococcus aureus }\end{array}$ & $\begin{array}{c}\text { Acinetobacter baumannii } \\
\text { Staphylococcus aureus }\end{array}$ \\
\hline 21 & Stroke & Enterobacter aerogenes & Enterobacter aerogenes \\
\hline
\end{tabular}

cfu: colony-forming units; HAP: hospital-acquired pneumonia. 
TABLE 4. Performance characteristics of non-bronchoscopic technique against the standard of bronchoscopic technique

\begin{tabular}{|l|c|}
\hline & Non-bronchoscopic technique (95\% CI) \\
\hline Sensitivity & $92.8 \%(64-99 \%)$ \\
Specificity & $85 \%(42-99 \%)$ \\
Positive predictive value & $92 \%(64-99 \%)$ \\
Negative predictive value & $85 \%(42-99 \%)$ \\
Positive likelihood ratio (conventional) & $6.5(1-40)$ \\
Positive likelihood ratio (weighted) & $13(7.5-22.3)$ \\
Negative likelihood ratio (conventional) & $0.08(0.012-0.57)$ \\
Negative likelihood ratio (weighted) & $0.16(0.025-1.07)$ \\
\hline
\end{tabular}

CI: confidence interval.

tained an excellent correlation of results between the two techniques. Furthermore, by using the same patient, and randomizing which technique to use first, as well as blinding the laboratory technician reading the cultures, we minimized bias. Our study also suggested that VAP is a diffuse disease involving multiple lobes, and samples obtained blindly have a comparable performance to FOB-guided samples s $^{11,20,21,27-30}$. Furthermore, histology-based reports suggest VAP is predominantly a dependent lung segment disease ${ }^{24}$ where is more likely that a nasogastric tube will go. Because the nasogastric tube has roughly the same size as a fiberoptic bronchoscope and unable to reach peripheral sections of the lung, we avoided complications such as pneumothorax.

Our study has several limitations, the two most important being that like any single center study, its results may not be generalizable to other settings. The second limitation of the study is the small sample size did not allow for subgroup analysis for specific admission diagnosis. However, the main objective of the study was to compare the microbiologic findings of the two techniques and we achieved that objective.

The results of our study have important implications in the care of patients with VAP in resourceconstrained settings, where the availability of bronchoscopes to confirm the diagnosis of VAP is limited.

We believe this innovative and simple technique should be validated in larger clinical trials, where antibiotic use, organ dysfunction improvement, and ultimately survival should be used as outcome measures.

\section{Declaration of conflict of interest}

All the authors reported no conflict of interest.

\section{REFERENCES}

1. Warren DK, Shukla SJ, Olsen MA, Kollef MH, Hollenbeak $\mathrm{CS}$, Cox MJ, et al. Outcome and attributable cost of ventilator-associated pneumonia among intensive care unit patients in a suburban medical center. Crit Care Med. 2003;31:1312-7.

2. Safdar N, Dezfulian C, Collard HR, Saint S. Clinical and economic consequences of ventilator-associated pneumonia: a systematic review. Crit Care Med. 2005; 33: 2184-93.

3. Kollef MH, Shorr A, Tabak YP, Gupta V, Liu LZ, Johannes RS. Epidemiology and outcomes of health-care-associated pneumonia: results from a large US database of culture-positive pneumonia. Chest. 2005;128:3854-62.
4. American Thoracic Society; Infectious Diseases Society of America. Guidelines for the management of adults with hospitalacquired, ventilator-associated and healthcare-associated pneumonia. Am J Respir Crit Care Med. 2005;171:388-416.

5. Ranes JL, Gordon SM, Chen P, Fatica C, Hammel J, Gonzales JP, et al. Predictors of long-term mortality in patients with ventilator-associated pneumonia. Am J Med. 2006;1 19:897. e13-9.

6. Heyland DK, Cook DJ, Marshall J, Heule M, Guslits B, Lang J, et al. The clinical utility of invasive diagnostic techniques in the setting of ventilator-associated pneumonia. Chest. 1999;115:1076-84.

7. Fagon JY, Chastre J, Wolff M, Gervais C, Parer-Aubas S, Stéphan F, et al. Invasive and noninvasive strategies for management for suspected ventilator-associated pneumonia. A randomized trial. Ann Intern Med. 2000;132:621-30.

8. Ost DE, Hall CS, Joseph G, Ginocchio C, Condon S, Kao E, et al. Decision analysis of antibiotic and diagnostic strategies in ventilator-associated pneumonia. Am J Respir Crit Care Med. 2003; 168:1060-7.

9. Minutoli R, Eden E, Brachfeld C. Bronchoalveolar lavage via a modified stomach tube in intubated patients with the acquired immunodeficiency syndrome and diffuse pneumonia. Thorax. 1990;45:771-3.

10. Knaus WA, Draper EA, Wagner DP, Zimmerman JE. APACHE II: a severity of disease classification system. Crit Care Med. 1985;13:818-29.

11. Pugin J, Auckenthaler R, Mili N, Janssens JP, Lew PD, Suter $\mathrm{PM}$. Diagnosis of ventilator-associated pneumonia by bacteriologic analysis of bronchoscopic and nonbronchoscopic "blind" bronchoalveolar lavage fluid. Am Rev Respir Dis. 1991;143:1121-9.

12. Baselski VS, el-Torky M, Coalson JJ, Griffin JP. The standardization of criteria for processing and interpreting laboratory specimens in patients with suspected ventilator-associated pneumonia. Chest. 1992;102 (5 Suppl 1):571S-579S.

13. Meduri GU, Chastre J. The standardization of bronchoscopic techniques for ventilator-associated pneumonia. Chest. 1992;102 (5 Suppl 1):557S-564S.

14. Baker AM, Bowton DL, Haponik EF. Decision making in nosocomial pneumonia. An analytic approach to the interpretation of quantitative bronchoscopic cultures. Chest. 1995;107:85-95.

15. Timsit JF, Misset B, Goldstein FW, Vaury P, Carlet J. Reappraisal of distal diagnostic testing in the diagnosis of ICU-acquired pneumonia. Chest. 1995;108:1632-9.

16. Deeks JJ, Altman DG. Diagnostic Tests 4: likelihood ratios BMJ. 2004;329:168-9.

17. Luna CM, Vujacich $P$, Niederman MS, Vay C, Gherardi C, Matera J, et al. Impact of BAL data on the therapy and outcome of ventilator-associated pneumonia. Chest. 1997;111:676-85.

18. Kollef MH, Ward S. The influence of mini-BAL cultures on patient outcomes: implications for the antibiotic management of ventilator-associated pneumonia. Chest. 1998;113:412-20.

19. Pham LH, Brun-Buisson $C$, Legrand $P$, Rauss A, Verra F, Brochard L, et al. Diagnosis of nosocomial pneumonia in mechanically ventilated patients. Comparison of a plugged telescoping catheter with the protected specimen brush. Am Rev Respir Dis. 1991;143(5 Pt 1):1055-61.

20. Marik PE, Brown WJ. A comparison of bronchoscopic vs blind protected specimen brush sampling in patients with suspected ventilator-associated pneumonia. Chest. 1995;108:203-7. 
21. Papazian L, Thomas $P$, Garbe L, Guignon I, Thirion $X$, Charrel J, et al. Bronchoscopic or blind sampling techniques for the diagnosis of ventilator-associated pneumonia. Am J Respir Crit Care Med. 1995;152(6 Pt 1):1982-91.

22. Kollef MH, Bock KR, Richards RD, Hearns ML. The safety and diagnostic accuracy of minibronchoalveolar lavage in patients with suspected ventilator-associated pneumonia. Ann Intern Med. 1995;122:743-8.

23. Fujitani S, Yu VL. Diagnosis of ventilator-associated pneumonia: focus on nonbronchoscopic techniques (nonbronchoscopic bronchoalveolar lavage, including mini-BAL, blinded protected specimen brush, and blinded bronchial sampling) and endotracheal aspirates. J Intensive Care Med. 2006;21:17-21.

24. Rouby JJ, Martin de Lassale E, Poete P, Nicolas MH, Bodin $\mathrm{L}$, Jarlier V, et al. Nosocomial bronchopneumonia in the critically ill. Histologic and bacteriologic aspects. Am Rev Respir Dis. 1992;146: 1059-66.

25. A'Court CH, Garrard CS, Crook D, Bowler I, Conlon C, Peto T, et al. Microbiological lung surveillance in mechanically ventilated patients, using non-directed bronchial lavage and quantitative culture. Q J Med. 1993;86:635-48.
26. Rouby JJ, Rossignon MD, Nicolas MH, Martin de Lassale E, Cristin S, Grosset J, et al. A prospective study of protected bronchoalveolar lavage in the diagnosis of nosocomial pneumonia. Anesthesiology. 1989;71:679-85.

27. Bello S, Tajada A, Chacón E, Villuendas MC, Senar A, Gascón M, et al. "Blind" protected specimen brushing versus bronchoscopic techniques in the aetiological diagnosis of ventilator-associated pneumonia. Eur Respir J. 1996;9:1494-9.

28. Papazian L, Autillo-Touati A, Thomas P, Bregeon F, Garbe $\mathrm{K}$, Saux P, et al. Diagnosis of ventilator-associated pneumonia: an evaluation of direct examination and presence of intracellular organisms. Anesthesiology. 1997;87:268-76.

29. Flanagan PG, Findlay GP, Magee JT, Ionescu A, Barnes RA, Smithies M. The diagnosis of ventilator-associated pneumonia using non-bronchoscopic, non-directed lung lavages. Intensive Care Med. 2000;26:20-30.

30. Leal-Noval SR, Alfaro-Rodríguez E, Murillo-Cabeza F, Garnacho-Montero J, Rey-Pérez J, Múñoz-Sánchez MA. Diagnostic value of the blind brush in mechanically ventilated patients with nosocomial pneumonia. Intensive Care Med. 1992;18: 410-4. 